\title{
SELEÇÃO DE BACTÉRIAS LÁTICAS ISOLADAS DE SUBSTRATO DA REGIÃO DO SEMIÁRIDO BAIANO COM POTENCIAL E/OU EFEITO PROBIÓTICO
}

\author{
$\underline{\text { Mahysa Ferreira Costa }}{ }^{1}$; Elinalva Maciel Paulo ${ }^{2}$
}

\author{
1. Bolsista PIBIC/FAPESB, Graduando em Ciências Biológicas, Universidade Estadual de Feira de Santana, e-mail: \\ mahysaferreiracosta@yahoo.com.br \\ 2. Orientador, Departamento de Ciências Biológicas, Universidade Estadual de Feira de Santana, e-mail: \\ elinalvamaciel@yahoo.com.br
}

PALAVRAS-CHAVE: Bactérias láticas; semiárido; inovação tecnológica; probiótico.

\section{INTRODUÇÃO}

Os produtos probióticos são constituídos principalmente pelas bactérias ácido láticas (BAL) e pelos bifidobacterium, pois esses micro-organismos são encontrados na microbiota intestinal humana, existindo vários trabalhos que demonstram sua eficácia e sua tolerância às barreiras biológicas do indivíduo. Entre as espécies de interesses utilizadas pelas indústrias de laticínios na elaboração de iogurte, leite fermentado, queijos e diversos derivados lácteos, encontramos basicamente as espécies do gêneros Lactobacillus , Lactococcus, Leuconostoc e Strepetococcus. Streptococcus thermophilus. (MARTIN, 2002). As exigências que um micro-organismo probiótico deve atender são: resistência ao ambiente ácido estomacal, à bile e às enzimas pancreáticas, adesão às células da mucosa intestinal, capacidade de colonização, ausências de translocação, ser um habitante normal das espécies alvo, exercer efeito antagônico sobre patógenos, capaz de exercer efeitos benéficos à saúde do hospedeiro e viabilidade populacional elevada, apresentando em torno de $10^{-6}-10^{-8}$ UFC por grama do produto (ANVISA, 2002).

Diante do crescente interesse da população por alimentos saudáveis, o mercado vem estimulando o aumento da produção de alimentos funcionais, sendo, benéficos à saúde humana por estarem relacionados à presença de bactérias láticas (OLIVEIRA; SILVA, 2011). Portanto, pode-se inferir que o semiárido baiano possui uma diversidade de micro-organismos que poderá ser utilizado na elaboração de diferentes produtos biotecnológicos.

\section{MATERIAL E MÉTODOS}

Micro-organismo e checagem da pureza da cultura lática: Foram utilizados isolados não identificados de bactérias láticas provenientes de produtos vegetais e de leite pertencentes à bacterioteca do LAMASP. Bactérias estas, provenientes de substratos vegetais (tomate, uva e maçã) e do leite.

Os isolados que estavam preservados no meio LDR 20\% (leite desnatado reconstituído 20\%) foram ativados três dias consecutivos no caldo MRS (DE MAN; ROGOSA; SHARPE, 1960). Incubados a $35^{\circ} \mathrm{C}$ por $24-72 \mathrm{~h}$ e realizado o teste preliminar para bactérias láticas (AXELSSON, 1993): o teste de catalase (mistura da colônia em uma gota de peróxido de oxigênio 3\%) e coloração de Gram. Culturas que apresentaram catalase negativa e na coloração de Gram morfologia de cocos ou bacilos (culturas individuais) de coloração roxa (positiva) foram confirmadas como puras para bactérias láticas. 
Identificação fenotípica (BERGEY'S, 2009): Foram realizados testes de identificação dos gêneros das linhagens de bactérias láticas isoladas realizando os seguintes testes: produção de gás a partir da glicose, capacidade em coagular o leite a 15 e $45^{\circ} \mathrm{C}$, crescimento em 4 e $8 \%$ de cloreto de sódio e redução do nitrato. Sendo todos os testes realizados em triplicata.

Teste de Antagonismo (BERGEY`S, 2009): Para avaliar a atividade antagonista foi utilizado o método de difusão em disco, sendo preparada suspensões das culturas de Escherichia coli e de Salmonella sp., equivalente a 0,5 da escala Mc Farland. Em seguida, uma alíquota de $100 \mu \mathrm{L}$ desta suspensão foi inoculada e espalhada com um cotonete esterilizado sobre toda a superfície do Ágar Nutriente. Após este procedimento foram colocados discos sobre a superfície do meio e, em seguida, estes foram impregnados com $10 \mu$ de culturas ativas (18h) dos isolados de bactérias láticas em confronto. As placas foram incubadas a $35^{\circ} \mathrm{C}$ por $24 \mathrm{~h}$ e a leitura dos resultados foi realizada através da observação da presença de halo de inibição. Este procedimento foi realizado em triplicata.

Tolerância às condições gástricas (Resistência a condições ácidas) (MEIRA et al, 2010): A resistência do isolado sob condição ácida foi avaliada em caldo MRS (pH 6,5) e caldo MRS ajustado a $\mathrm{pH} 3,0 \mathrm{com} \mathrm{HCl}$ concentrado. Os tubos contendo o meio de cultivo com $\mathrm{pH}$ diferentes foram deixadas durante $3 \mathrm{~h}$ na temperatura ambiente e, em seguida, foram semeados pelo método "pour plate", incubados a $35^{\circ} \mathrm{C} / 48 \mathrm{~h}$, sendo observado o crescimento das placas. Todos os testes foram realizados em triplicata.

\section{RESULTADOS E DISCUSSÃO}

As bactérias láticas pertencentes à bacterioteca do Lamasp foram identificadas com morfologia bacilar, às isoladas de substratos vegetais (uva, maçã e tomate), e morfologia de cocos a bactéria isolada do leite. Todas as bactérias apresentaram-se como gram positivas, e no teste de catalase, resultado negativo. A partir da leitura dos testes preliminares com $48 \mathrm{~h}$ de inoculado, as bactérias láticas apresentaram resultado negativo para o teste de produção de gás, sendo caracterizadas como homofermentativas, pela ausência de produção de gás. No teste de halotolerância a $8 \%\left(45^{\circ} \mathrm{C}\right)$ as bactérias apresentaram pouco crescimento, contudo, a $4 \%\left(15^{\circ} \mathrm{C}\right)$ nenhuma das bactérias avaliadas apresentaram crescimento. Na concentração de $6 \%\left(35^{\circ} \mathrm{C}\right)$ todas as bactérias apresentaram um bom crescimento. Neste teste de halotolerância, a $45^{\circ} \mathrm{C}$ e $15^{\circ} \mathrm{C}$, as bactérias por se encontraram em situação de estresse, com temperatura diferente do seu ótimo e em um meio concentrado de sal $(\mathrm{NaCl})$, acabou dificultando ou até mesmo impedindo o crescimento de tais bactérias sob tais condições. Diante do resultado obtido, podemos classificar as bactérias láticas isoladas, do leite e de vegetais, como termodúricas. Para o teste de lactofermentação a $45^{\circ} \mathrm{C}$ todas as bactérias coagularam o meio, sem soro, na temperatura de $15^{\circ} \mathrm{C}$ as bactérias do tomate e do leite não obtiveram nenhum crescimento, a uva e a bactéria da maçã apresentaram pouco crescimento, com coágulo não firme. $\mathrm{Na}$ temperatura de $35^{\circ} \mathrm{C}$ todas as bactérias apresentaram formação de coágulo e pouco ou nenhum soro. 
Como resultado no teste do nitrato, todas as bactérias láticas apresentaram resultado negativo, não alterando a coloração do meio quando acrescido dos reagentes alfanaftol e ácido sulfanílico.

No teste de antagonismo as bactérias láticas em questão não formaram halo de inibição contra as bactérias patogênicas E. coli e Samonella sp. Quanto ao teste de tolerância às condições gástricas, as bactérias láticas apresentaram crescimento quando submetidas ao meio acidificado, $\mathrm{pH}$ 3,0, durante 3 horas. Sendo assim, provavelmente conseguirão resistir às condições gástricas durante o período de digestão do nosso organismo. Todos os testes foram realizados em triplicata.

As bactérias láticas avaliadas não conseguiram inibir os patógenos intestinais, porém não são consideradas inviáveis para utilização de benefícios do hospedeiro, sendo capazes de ocasionar melhoras no sistema imunológico, já que resistem as condições fisiológicas normais do hospedeiro. No entanto, são necessários mais pesquisas e testes com as bactérias.

Tabela: Testes e resultados

\begin{tabular}{|c|c|c|c|c|}
\hline \multirow[b]{2}{*}{$\begin{array}{c}\text { Bactérias } \\
\text { Láticas }\end{array}$} & \multicolumn{3}{|c|}{ Halotolerância } & \\
\hline & $4 \%$ & $6 \%$ & $8 \%$ & Produção de gás \\
\hline Uva & $\begin{array}{l}\text { Não houve } \\
\text { crescimento }\end{array}$ & $\begin{array}{l}\text { Bom } \\
\text { crescimento }\end{array}$ & $\begin{array}{l}\text { Pouco } \\
\text { crescimento }\end{array}$ & Negativo \\
\hline Maçã & $\begin{array}{l}\text { Não houve } \\
\text { crescimento }\end{array}$ & $\begin{array}{l}\text { Bom } \\
\text { crescimento }\end{array}$ & $\begin{array}{l}\text { Pouco } \\
\text { crescimento }\end{array}$ & Negativo \\
\hline Tomate & $\begin{array}{l}\text { Não houve } \\
\text { crescimento }\end{array}$ & $\begin{array}{l}\text { Bom } \\
\text { crescimento }\end{array}$ & $\begin{array}{l}\text { Pouco } \\
\text { crescimento }\end{array}$ & Negativo \\
\hline Leite & $\begin{array}{l}\text { Não houve } \\
\text { crescimento }\end{array}$ & $\begin{array}{l}\text { Bom } \\
\text { crescimento }\end{array}$ & $\begin{array}{l}\text { Pouco } \\
\text { crescimento }\end{array}$ & Negativo \\
\hline
\end{tabular}

\begin{tabular}{|l|l|l|l|}
\hline \multirow{2}{*}{ Bactérias Láticas } & \multicolumn{3}{|c|}{ Lactofermentação } \\
\cline { 2 - 4 } & \multicolumn{1}{|c|}{$\mathbf{1 5}^{\circ} \mathbf{C}$} & \multicolumn{1}{c|}{$\mathbf{3 5}^{\circ} \mathbf{C}$} & \multicolumn{1}{|c|}{$\mathbf{4 5}^{\circ} \mathbf{C}$} \\
\hline Uva & Coágulo não firme & $\begin{array}{l}\text { Coágulo firme e sem } \\
\text { soro }\end{array}$ & $\begin{array}{l}\text { Coágulo firme e sem } \\
\text { soro }\end{array}$ \\
\hline Maçã & Coágulo não firme & $\begin{array}{l}\text { Coágulo firme e sem } \\
\text { soro }\end{array}$ & $\begin{array}{l}\text { Coágulo firme e sem } \\
\text { soro }\end{array}$ \\
\hline Tomate & $\begin{array}{l}\text { Não houve } \\
\text { crescimento }\end{array}$ & $\begin{array}{l}\text { Coágulo firme e sem } \\
\text { soro }\end{array}$ & Coágulo não firme \\
\hline
\end{tabular}




\begin{tabular}{|l|l|l|l|}
\hline Leite & $\begin{array}{l}\text { Não houve } \\
\text { crescimento }\end{array}$ & $\begin{array}{l}\text { Coágulo firme e sem } \\
\text { soro }\end{array}$ & $\begin{array}{l}\text { Coágulo firme e sem } \\
\text { soro }\end{array}$ \\
\hline
\end{tabular}

\begin{tabular}{|l|c|c|c|c|}
\hline \multirow{2}{*}{\multicolumn{1}{|c|}{$\begin{array}{c}\text { Bactérias } \\
\text { Láticas }\end{array}$}} & E. coli & Salmonela sp. & pH 6,5 & pH 3,0 \\
\cline { 2 - 5 } Uva & $\begin{array}{c}\text { Nenhuma } \\
\text { Maçã } \\
\text { Tomate } \\
\text { Le intou hibição }\end{array}$ & $\begin{array}{c}\text { Nenhuma } \\
\text { apresentou halo } \\
\text { de inibição }\end{array}$ & $\begin{array}{c}\text { Apresentaram } \\
\text { ótimo } \\
\text { crescimento }\end{array}$ & Cresceram \\
\hline
\end{tabular}

\section{CONSIDERAÇÕES FINAIS}

A benéfica influência dos probióticos diante da microbiota gastrointestinal inclui fatores como efeitos antagônicos, competição e efeitos imunológicos, resultando em um aumento da resistência contra patógenos. Sendo assim, utilizar culturas probióticas propicia a multiplicação de bactérias benéficas, em detrimento à proliferação de bactérias potencialmente prejudiciais, reforçando os mecanismos naturais de defesa do hospedeiro. No entanto, as cepas testadas não atenderam ao critério efeito antagônico sobre os patógenos intestinais, mas não inviabilizaram a sua utilização para outros benefícios do hospedeiro, a exemplo da reposição da microbiota intestinal ou a estimulação do sistema imunológico, uma vez que toleraram as condições fisiológicas normalmente existentes no hospedeiro.

\section{REFERÊNCIAS}

AXELSSON, L. 1993. Lactic acid bacteria: classification and physiology. In: SALMINEN, S. VON WRIGHT, A. Lactic acid bacteria. New York: Marcel Dekker, p.1 -63.

BERGEY'S MANUAL OF SYSTEMATIC BACTERIOLOGY. The Firmicutes, vol. 3, 2009.

DE MAN, J.C.; ROGOSA, M.; SHARPE, M.E.A medium for cultivation of lactobacilli.J. Appl. Bacteriol., 23,130-135, 1960.

Informe Técnico ANVISA n ${ }^{\circ}$, de 15 de janeiro de 2002. Assunto: Definição de categorias de alimentos de acordo com o Regulamento Técnico de Substâncias Bioativas e Probióticos Isolados com Alegação de Propriedades Funcionais e ou de Saúde.

MEIRA, S. M. M. Identificação e resistência a barreiras biológicas de bactérias lácticas isoladas de leite e queijo de ovelha. 2010

OLIVEIRA, C. P. e SILVA, J. A. LEITE FERMENTADO PROBIÓtico E SUAS IMPLICAÇÕES NA SAÚDE. Revista Verde (Mossoró - RN - Brasil) v.6, n.3, p. 25 -31 julho / setembro de 2011. 